\title{
Conversion of forestry land back to productive pasture
}

\author{
Bay of Plenty Farm \& Pastoral Research, C/- NZ Forest Research Institute, PB 3020, Rotorua \\ M. F. HAWKE \\ martin.hawke@xtra.co.nz
}

\begin{abstract}
Large areas of pine forests have been logged and the land sold to farmers for converting to pasture in the South Waikato district. This land use change is expected to continue, given the present commodity prices. A trial was conducted on an ex-forest site at Rotorua to assess the feasibility of converting land from forestry to pastoral agriculture. The establishment of pasture (ryegrass and white clover) on an ex-forest site was successful and results after 4 years indicated there were no major problems with the conversion.

An application of $4 \mathrm{t}$ lime/ha lifted soil $\mathrm{pH}$ levels into the optimum range of 5.8-6.0 and an annual maintenance dressing of $40 \mathrm{~kg}$ phosphorus (P) /ha has more than maintained optimum Olsen P levels of 35-45 $\mu \mathrm{g} / \mathrm{ml}$ for pasture growth. It is expected however that commercial sites where post-forest soil $\mathrm{P}$ levels were lower than on the Rotorua trial site, would require higher capital $\mathrm{P}$ fertiliser input. Soil fauna surveys indicated a recolonisation of some soil macro fauna e.g. earthworms, grass grubs and clover root weevil. Recommendations for converting pines to pasture include removal of stumps and forest debris (where practical), vigorous weed control and the application of nutrients such as phosphate that promote pasture production.
\end{abstract}

Keywords: forestry, soil Olsen phosphorus, soil pH, pasture, Pinus radiata

\section{Introduction}

About 4000 ha of high quality land in South Waikato on the margins of forestry estates are being logged and sold to neighbouring dairy farmers (I. Elliott pers. comm.). Two thousand hectares of this land have already been converted to pasture. This experience is being replicated in other parts of New Zealand e.g. Bay of Plenty, Southland and Canterbury with up to 10000 ha being suitable for conversion over the next 5 years. In addition, many forestry blocks (pine \& eucalypt) are due to be logged on land suitable for sheep and beef production. Recent changes in forest ownership suggest large areas of existing forest may be converted to pasture, depending on economic viability and financial projections on commodity returns.

Conveniently, a trial on the Tikitere Agroforestry research area, near Rotorua has monitored the effects of a previous forestry regime on a range of agricultural parameters since 1999. The Tikitere Agroforestry Trial (McQueen et al. 1976) was planted with Pinus radiata in 1973 and logged in 1999.

This paper will describe the long term soil chemical results from the Tikitere trial and report on the effects of the first 4 years of the conversion to pasture. Discussion will include practical management advice for farmers to consider.

\section{Trial details and methods}

A range of parameters were measured at the Agroforestry trial at Tikitere for 26 years, including soil $\mathrm{pH}$ and nutrient levels (Hawke \& O'Connor 1993). The trial was on a recent volcanic sandy loam (typic Vitrudand) classified as Rotoiti sandy loam (Soil Survey Staff 1992).

A 1 ha site, previously stocked at $400 \mathrm{stems} / \mathrm{ha}$ (sph) was cleared of forest debris and fenced. In addition, a small area $(20 \mathrm{~m} \times 20 \mathrm{~m})$ within this 1 ha was cleared of stumps as an example of what may be required by a farmer to establish pasture on land completely cleared of forest remnants. A 1 ha permanent pasture plot had been maintained on the trial for the past 29 years as a control site. After logging in 1999, a replicated lime / phosphorus (P) plot trial was laid down in autumn 2000. The trial consisted of eight treatments with five replicates and the plot size was $7 \mathrm{~m} \times 12 \mathrm{~m}$. The 1 ha area was sprayed with 12.5 1/ha of Roundup Renew herbicide, fertiliser applied and a pasture seed mixture of $25 \mathrm{~kg}$ prillcote Pacific ryegrass and $5 \mathrm{~kg}$ Tahora white clover broadcast over the area. The lime treatments $(0,2,4$ and $6 \mathrm{t} / \mathrm{ha})$ were applied at laying down and the $\mathrm{P}$ treatments $(0$ and 40 $\mathrm{kg} / \mathrm{ha}$ ) and basal potassium $(\mathrm{K})$ and magnesium $(\mathrm{Mg})$ (90 and $30 \mathrm{~kg} / \mathrm{ha}$ respectively) applied at laying down and then each autumn/early winter. Soil sulphate-sulphur (S) levels were adequate for optimum pasture growth. The stumped area was fertilised with $2 \mathrm{t}$ lime/ha and the same units of $\mathrm{P}, \mathrm{K}$ and $\mathrm{Mg}$ as the main trial.

Soil chemical samples were taken at 0-75 $\mathrm{mm}$ depth each autumn and analysed for soil $\mathrm{pH}$ and Olsen $\mathrm{P}$ using the Ministry of Agriculture and Fisheries quick test procedures (Cornforth \& Sinclair 1984). Soil fauna populations were measured in autumn 2002 from the open pasture control paddock, treatments 1 and 7 (control and $4 \mathrm{t} \mathrm{lime}+40 \mathrm{~kg} \mathrm{P} / \mathrm{ha}$ ) and the stumped area. A $10 \mathrm{~cm}$ diameter corer was used to take soil samples to 
Figure 1 Historical soil $\mathrm{pH}$ levels $(0-75 \mathrm{~mm})$ at the Tikitere Agroforestry trial (vertical bars show SED).

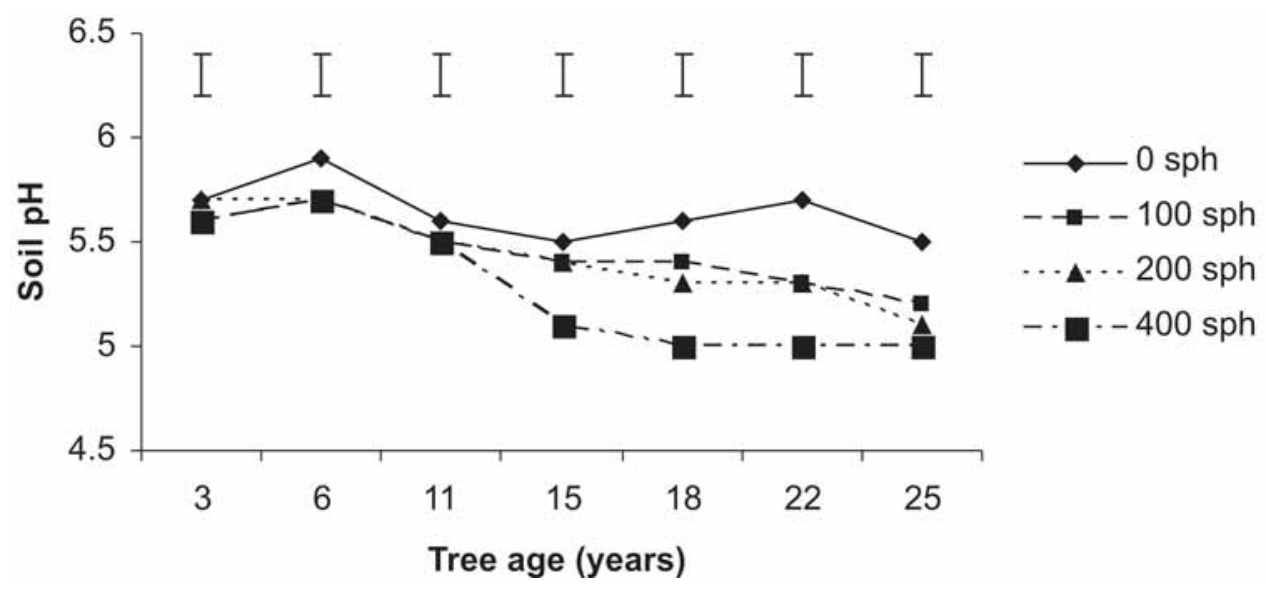

Figure 2 Historical soil Olsen P levels at the Tikitere Agroforestry trial.

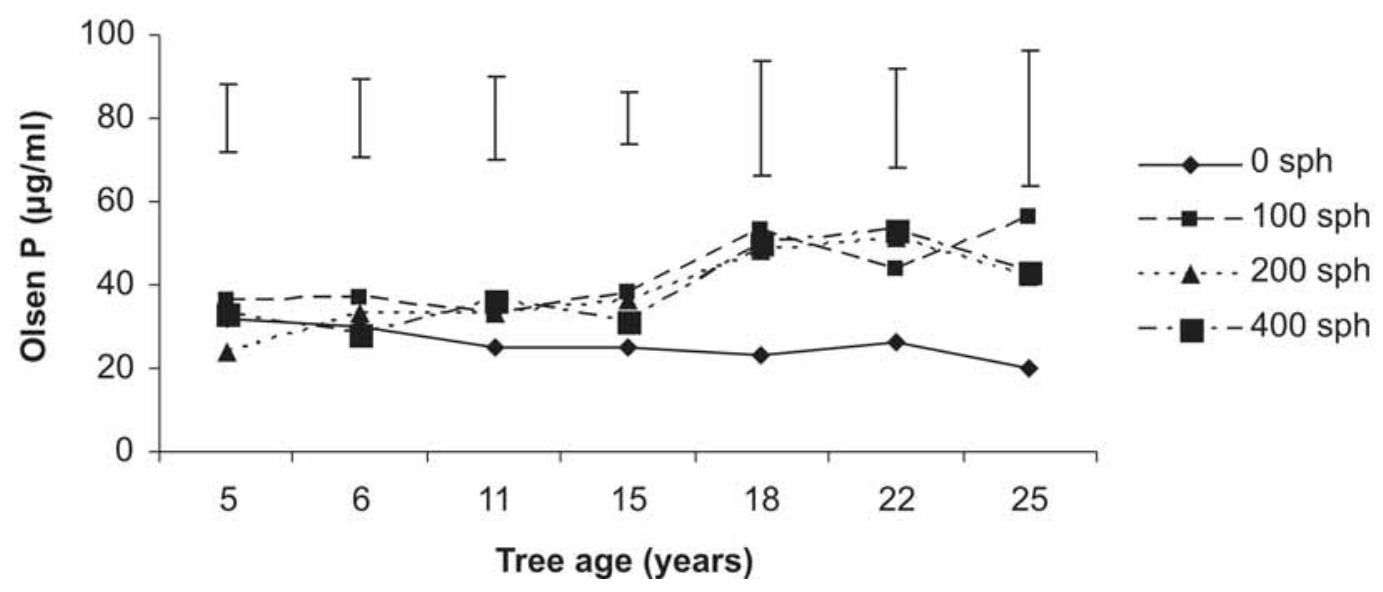

Figure 3 The effects of lime on soil pH (vertical bars show SED).

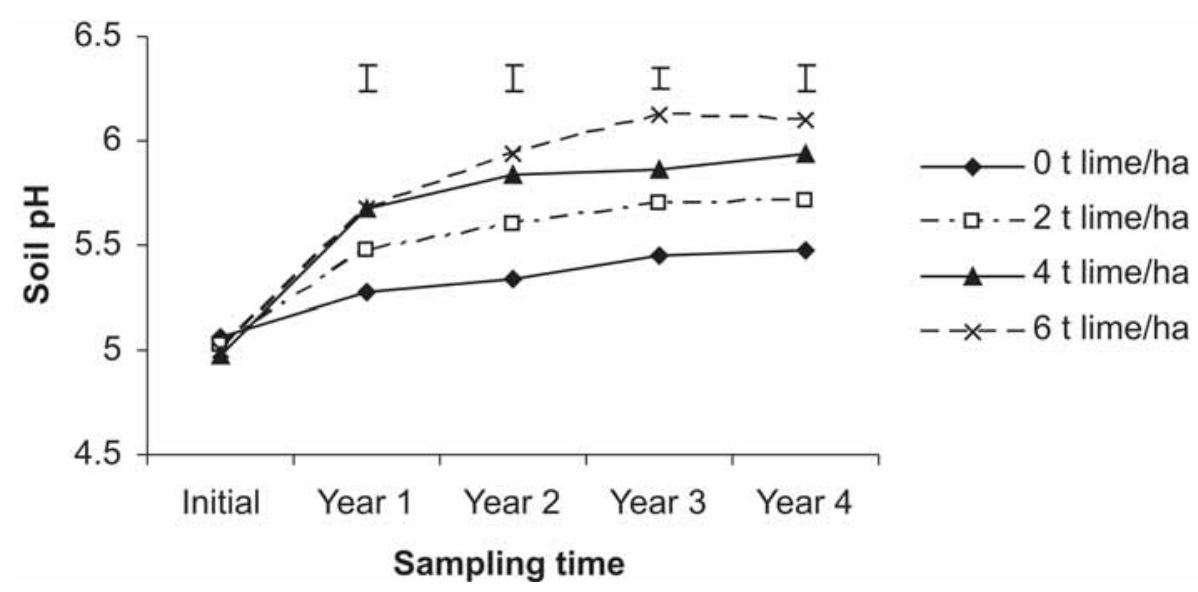


Figure 4 The effects of $\mathrm{P}$ fertiliser application on soil Olsen $\mathrm{P}$ levels (vertical bars show SED).

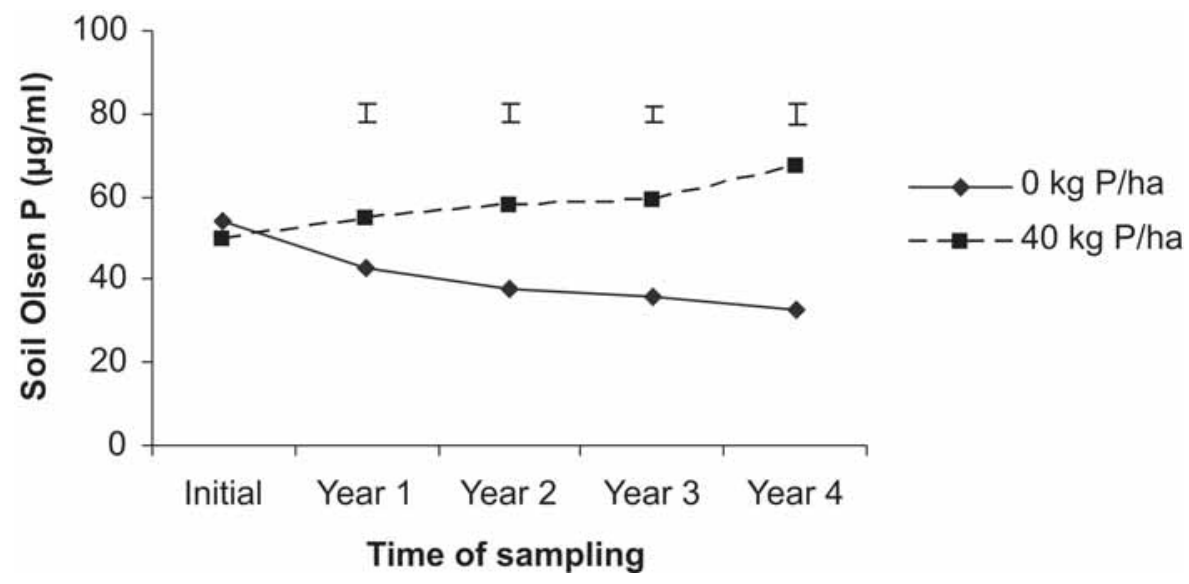

Figure 5 Pasture yield ( $\mathrm{kg} \mathrm{DM} / \mathrm{ha}$ ) after 2 years of conversion. Vertical bars show SED. (OL/OP = No lime/no phosphorus $(\mathrm{P}), \mathrm{OL} / 40 \mathrm{P}=$ No lime/ 40kg $\mathrm{P} / \mathrm{ha}, 4 \mathrm{~L} / \mathrm{OP}=4 \mathrm{t}$ lime $/ \mathrm{ha} / \mathrm{no} \mathrm{P}, 4 \mathrm{~L} / 40 \mathrm{P}=4 \mathrm{t}$ lime $/ \mathrm{ha} / 40 \mathrm{~kg}$ P/ha).

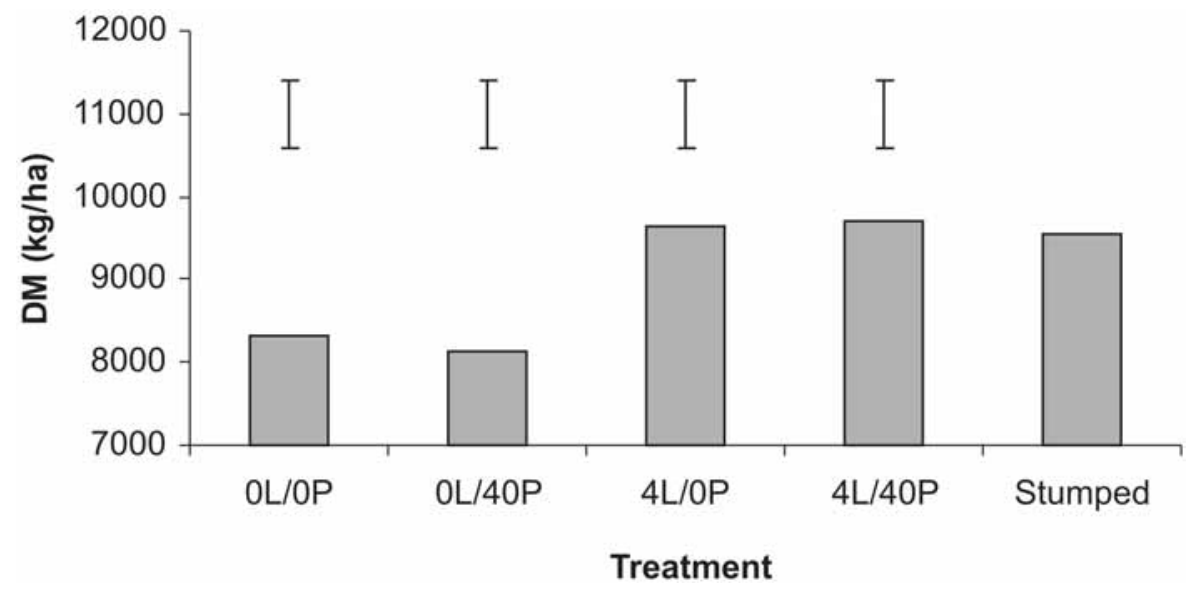

a depth of $15 \mathrm{~cm}$ randomly along two parallel transects spanning the paddock/plot. The samples were hand sorted in the field and all macro fauna, excluding ants, were recorded. One hundred samples were taken from the pasture control paddock, 10 samples from each of the small plots and 30 samples from the stumped area.

Pasture production was measured for the growing season 2002-2003 from selected treatments at six week intervals using the single trim and cut technique (Piggott 1986) and small pasture exclosure cages $\left(5 \times 0.22 \mathrm{~m}^{2} /\right.$ treatment). Dry matter (DM) yields are expressed on a total area basis i.e. stumps are not included. White clover cover was visually assessed on three occasions during the 2001-2002 growing season, using a 0-10 scale for percentage clover in the plot.

The trial was periodically grazed with a mob of 20-30 beef cows to leave a residual pasture cover of 1500$1600 \mathrm{~kg} \mathrm{DM} / \mathrm{ha}$.
The data were analysed using standard analysis of variance procedures (Genstat 5 Committee 1993).

\section{Results}

\section{Soil chemical effects}

The historical Tikitere soil chemical results indicated there was no significant change in soil $\mathrm{pH}$ and available $\mathrm{P}$ (Olsen P) in the $0-75 \mathrm{~mm}$ soil depth until after Year 11 of the tree rotation (Hawke \& O'Connor 1993). Increasing tree age and tree stocking resulted in increased soil acidity and Olsen P, mainly in the higher tree stocking treatment of $400 \mathrm{sph}$ in the second half of the tree rotation (Figures 1 and 2).

In the new trial, a dressing of $4 \mathrm{t}$ lime/ha lifted the soil $\mathrm{pH}$ from an initial level of 5.0 to a level of 5.9 (Figure 3). However $2 \mathrm{t}$ lime/ha also achieved a large part of this effect, raising the soil $\mathrm{pH}$ from 5.0 to 5.7, both in the trial and stumped area. There was a natural increase in soil 
Table 1 Treatment effects of visual white clover composition (0-10 scale) in Year 2 of conversion trial.

\begin{tabular}{lcccc}
\hline & Rate $(\mathrm{t} / \mathrm{ha})$ & November 2001 & January 2002 & March 2002 \\
\hline Lime & 0 & 2.20 & 4.30 & 4.80 \\
& 2 & 3.40 & 6.40 & 6.80 \\
\multirow{2}{*}{ SED } & 4 & 3.60 & 6.20 & 6.80 \\
Phosphorus & 6 & 3.40 & 6.10 & 7.00 \\
Sate $(\mathrm{kg} / \mathrm{ha})$ & 0.56 & 0.64 & 0.39 \\
SED & 0 & 3.05 & 6.00 & 6.30 \\
\hline
\end{tabular}

Table 2 Soil macro fauna densities (no. $/ \mathrm{m}^{2}$ ) measured in April 2002.

\begin{tabular}{lcccc}
\hline Fauna species & Old pasture & $\begin{array}{c}\text { New pasture } \\
\text { No lime and } P\end{array}$ & $\begin{array}{c}\text { New pasture } \\
\text { Lime }+P\end{array}$ & Stumped area \\
\hline Earthworms & 20 & 25 & 74 & 4 \\
Grass grub & 20 & 0 & 25 & 11 \\
Clover root weevil & 93 & 629 & 1763 & 78 \\
\hline
\end{tabular}

$\mathrm{pH}$ from 5.0 to 5.4 where no lime had been applied.

There was an increase in soil Olsen $P$ to the annual application of $40 \mathrm{~kg} \mathrm{P} / \mathrm{ha}$ of $27 \mu \mathrm{g} / \mathrm{ml}$ over the 4 year period. Olsen $\mathrm{P}$ decreased each year where phosphate had not been applied from an initial figure of 52 to $33 \mu \mathrm{g} /$ $\mathrm{ml}$ at Year 4 (Figure 4).

\section{Pasture production and clover cover}

There was an increase in pasture DM production to $4 \mathrm{t}$ lime/ha, but no pasture production increase to $P$ fertiliser application and no interaction between lime and $\mathrm{P}$ (Figure 5). The stumped area performed similarly to the $4 \mathrm{t} \mathrm{lime/}$ ha treatment.

There was a significant increase in clover cover with the addition of lime on all three assessment dates. There was no increase to the $\mathrm{P}$ treatment (Table1).

\section{Soil macro fauna populations}

Earthworms were more abundant in the new pasture, particularly in the plots that had received lime and P. The stumping operation reduced earthworm numbers drastically. Grass grub and clover root weevil populations were also reduced in the stumped area. Clover root weevil numbers increased dramatically in the new pasture, particularly in the lime and $\mathrm{P}$ fertilised plots (Table 2).

\section{Discussion}

The conversion of land that had been in radiata pine forestry for 26 years to pasture appears to present no problems if adequate $\mathrm{P}, \mathrm{K}$ and $\mathrm{S}$ fertiliser and lime are used and weed control is achieved. The high Olsen P (50 $\mu \mathrm{g} / \mathrm{ml}$ ) level on this site at the end of the forestry rotation was in part due to the pasture having been fertilised for the first 10 years of the tree rotation to optimise pasture production under the trees. The rate of $40 \mathrm{~kg} \mathrm{P} / \mathrm{ha}$ that was used was greater than required for maintenance of soil Olsen $\mathrm{P}$ as evidenced by the increase in test level over 4 years.

In a commercial forest, fertiliser would generally not have been applied and the available P level would be low. This was evident from samples taken on a conversion in South Waikato where Olsen P figures were in the range of $1-4 \mu \mathrm{g} / \mathrm{ml}$ after 65 years in pine trees (Elliott pers. comm.). Consequently successful establishment of pasture on such sites would require a significant capital input of phosphate to reach the target Olsen P soil test range of $35-45 \mu \mathrm{g} / \mathrm{ml}$ for pumice soils (Morton \& Roberts 1999).

Increases in topsoil acidity have been observed in other forested sites in New Zealand (Davis 1998; Giddens et al. 1997; Parfitt et al. 1997) although in the South Waikato conversions that were monitored, soil $\mathrm{pH}$ under the pine trees was 5.9 - 6.1 (Elliott pers. comm.). This was most probably due to the high buffering capacity of the Tirau Allophanic soil type (Edmeades et al. 1985). The natural increase in soil $\mathrm{pH}$ after logging may have been due to soil disturbance, breakdown (and removal) of needles and debris and the absence of new needle deposition. However, $\mathrm{pH}$ did not increase sufficiently to avoid the need to add lime. Soil testing is therefore vital to determine the fertiliser and lime requirements after a crop of trees.

If the tree stumps are left in the ground, it is recommended to scarify the soil between the stumps if possible to assist burial of the grass seed and to aid germination. The actual mechanics of converting forestry to pasture are similar to the early development of pasture from indigenous bush. Pasture in the stumped area was 
healthy, despite much raw pumice being brought to the surface when the stumps were excavated. After the logging operation, weed germination was rampant and weed control was imperative during the initial stages of re-establishing pasture.

The advantage of leaving the stumps in the ground after logging is that the root systems will bind the soil for some years and reduce erosion (Maclaren 1993). It is probably uneconomic to remove the stumps on hill country. The decay of tree stumps is being monitored and after 5 years, some decomposition is noticeable. Despite the cost of stumping $(\$ 1000-\$ 2000 /$ ha), there is a definite advantage of removing stumps on flat and rolling topography, due to improved pasture establishment and an increase in the area of pasture previously occupied by stumps. Furthermore, weeds were less of a problem and spraying for weeds with ground machinery was less hazardous without the tree stumps. Farmer practice suggests that cultivation and growing of a crop before re-grassing assists in reducing weeds.

The small effect that lime and P had on increasing pasture production was probably because soil fertility levels were initially reasonably high and $\mathrm{P}$ was not limiting. Under converted forest soils with a low Olsen $\mathrm{P}$ as observed in the South Waikato conversions, a response to $\mathrm{P}$ fertiliser is most likely. The introduction of new high producing pasture cultivars, the judicious use of nitrogen fertiliser and careful grazing management should help to optimise pasture yields.

Pastoral soil fauna populations at tree age 26 years of the pine rotation in the $400 \mathrm{sph}$ treatment were nil (Willoughby \& Hawke unpublished). The soil fauna survey results after 2 years of the conversion to pasture indicated that pastoral fauna populations recovered quickly and responded to lime in particular. The soil fauna measurements did not include a lime only treatment, but the pasture production and soil chemical results indicated that $\mathrm{P}$ was not limiting and would not have influenced the result. The dramatic increase in clover root weevil numbers is attributed to the absence of root feeding clover nematodes and the increased clover cover, vigour and quality of the plants unrestrained by inadequate fertiliser.

Several thousand hectares of radiata pine are being converted to pasture for dairy production in the South Waikato region and farmers have demonstrated that with judicious management, pasture can be successfully established. A range of land clearing techniques is being used, such as stump removal, mulching and leaving them in the ground. Where land is undergoing a change in use, there are opportunities to consider environmental sustainability in the planning stages.

There is a huge potential for conversion of forests to pasture throughout New Zealand, dependant on the economics of land purchase and commodity prices. The fact that Forest Companies are prepared to sell land that is sometimes only part way through a tree rotation, with little value placed on the timber suggests there are major economic changes taking place. The conversions are also being extended to eucalypt plantations, primarily in the Bay of Plenty region, where short rotation stands of 1012 years are due to be harvested. Because of the young age of these stands which were previously in pasture, it is not expected there will be any unforeseen management problems relating to conversion to pasture.

\section{Conclusions}

Results after 4 years of a fertiliser experiment on the Tikitere Agroforestry trial site indicated that the addition of $4 \mathrm{t}$ lime/ha lifted soil $\mathrm{pH}$ levels to the adequate range for pasture growth. On this site an application of $40 \mathrm{~kg}$ $\mathrm{P} /$ ha was more than adequate to maintain Olsen $\mathrm{P}$ levels in the recommended range of $35-45 \mu \mathrm{g} / \mathrm{ml}$ for pumice soils. The actual rate required should be determined by preliminary soil $\mathrm{P}$ analysis. Weed infestation following logging was a major problem requiring careful management. Farmers in South Waikato have demonstrated that conversion from forestry to pastoral farming presented no major obstacles, providing good farm management techniques were used.

\section{ACKNOWLEDGEMENTS}

The author thanks Ian Elliott for information on commercial farm conversions and Bruce Willoughby for conducting the soil fauna population survey. The trial was funded by FoRST, Forest and Farm Plantation Management Cooperative and Ballance Agri-Nutrients Ltd. The author acknowledges the land owner, Paehinahina- Mourea Incorporation and Fletcher Forests Ltd. The Tikitere trial was managed by AgResearch.

\section{REFERENCES}

Cornforth, I.S.; Sinclair, A.G. 1984. Fertiliser and Lime Recommendations for Pastures and Crops in New Zealand. Second Revised Edition, MAF, Wellington. $66 \mathrm{pp}$.

Davis, M.R. 1998. Soil impacts of afforestation in the high country. New Zealand Forestry 42: 34-38.

Edmeades, D.C.; Wheeler, D.; Waller, J.E. 1985. Comparison of methods for determining lime requirements of New Zealand soils. New Zealand Journal of Agricultural Research 28: 93-100.

Genstat 5 Committee 1993. Genstat 5 release 3, reference manual. Oxford, Clarendon Press, UK.

Giddens, K.M.; Parfitt, R.L.; Percival, H.J. 1997. Comparison of some soil properties under Pinus radiata and improved pasture. New Zealand Journal 
of Agricultural Research 40: 409-416.

Hawke, M.F.; O'Connor, M.B. 1993. Soil pH and nutrient levels at Tikitere Agroforestry Research Area. New Zealand Journal of Forestry Science 23: 40-48.

McQueen, I.P.M.; Knowles, R.L.; Hawke, M.F. 1976.

Evaluating forest farming. Proceedings of the New Zealand Grassland Association 37(2): 203-207.

Maclaren, J.P. 1993. Radiata Pine Growers' Manual, Chapter 15. FRI Bulletin No. 184. 140 pp.

Morton, J.D.; Roberts, A.H.C. 1999. Fertiliser use on New Zealand sheep and beef farms. New Zealand Fertiliser Manufacturers' Research Association booklet. $37 \mathrm{pp}$.

Parfitt, R.L.; Percival, H.J.; Dahlgren, R.A.; Hill, L.F. 1997. Soil and solution chemistry under pasture and radiata pine in New Zealand. Plant and Soil 191: 279290.

Piggot, G.J. 1986. Methods for estimating pasture dry matter on dairy farms in Northland. Proceedings of the New Zealand Grassland Association 47: 243-247. Soil Survey Staff 1992. Keys to Soil Taxonomy, 5th edition. SSMS technical monograph No. 19. Blacksburg, Virginia, Pocahontas Press, USA. 556 pp. 